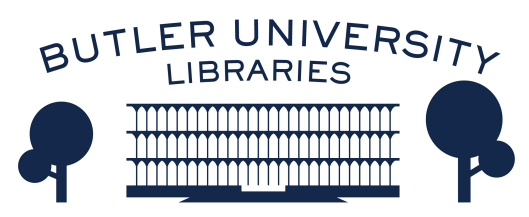

Journal of Hindu-Christian Studies

Volume 19

Article 10

January 2006

\title{
Embodying "Bhakti Rasa" in Bharata Natyam: An Indian-Christian Interpretation of "Gayatri" Mantra through Dance
}

Katherine C. Zubko

Follow this and additional works at: https://digitalcommons.butler.edu/jhcs

Part of the Religion Commons

\section{Recommended Citation}

Zubko, Katherine C. (2006) "Embodying "Bhakti Rasa" in Bharata Natyam: An Indian-Christian Interpretation of "Gayatri" Mantra through Dance," Journal of Hindu-Christian Studies: Vol. 19, Article 10. Available at: https://doi.org/10.7825/2164-6279.1365

The Journal of Hindu-Christian Studies is a publication of the Society for Hindu-Christian Studies. The digital version is made available by Digital Commons @ Butler University. For questions about the Journal or the Society, please contact cbauman@butler.edu. For more information about Digital Commons @ Butler University, please contact digitalscholarship@butler.edu. 


\title{
Embodying Bhakti Rasa in Bharata Natyam: An Indian-Christian Interpretation of Gayatri Mantra through Dance
}

\author{
Katherine C. Zubko \\ Emory University
}

\begin{abstract}
AS the five female dancers from the IndianChristian fine art college of Kalai Kaviri encircle the South Indian brass lamp, or vilakku, awakening it to life with the flames from their own individual votives, the beginning melody of a song cues the women to stretch out their arms in preparation to rise from their seated positions and dance. As they raise their arms in unison, the light glinting off their bangles and gold threaded costumes, the Sanskrit words Om Bhur Bhuvah Svah signal the invocatory phrase of the popular Gayatri mantra chanted daily by many Hindus all over the world. By the time the second repetition of the mantra is completed, the bodies of the dancers are fanned out from behind a single dancer, creating the visual image of the sun with its rays beaming outwards to all directions of the universe. This pose aptly conveys homage to the sun god, Savitr or Surya, one of the Hindu deities associated with the Gayatri mantra. ${ }^{105}$ At the same time, the choreographer notes that this pose, performed during cultural programs in Hindu temples and liturgical services in churches and cathedrals across England during June 2004, also evokes the idea of Jesus as the Light of the World. Drawing upon the Kalai Kaviri presentations of the Gayatri mantra as a lens, I argue that
\end{abstract}

through a performative embodied understanding of bhakti rasa, an aesthetic sentiment typically defined as a "devotional" mood, contemporary performers of Bharata Natyam ${ }^{106}$ create a critical framework that makes fluidity of religious narratives and meanings possible across religious traditions.

Through the contextualized Kalai Kaviri performances of the Gayatri mantra, I will, first of all, concretely make the distinction between embodied, performed rasa in comparison to the predominant textual, philosophical theories on rasa, with special attention to the cultivation of bhakti rasa. Second, I highlight how these particular bodies dancing specifically on the Gayatri mantra shape new meanings of the mantra through a condensed performance analysis. And third, I suggest through a cultural reading of the indigenous category of bhakti rasa, an expansion of Barbara Holdrege's idea of "devotional bodies" to account for embodied knowledge from within the study of religion.

\section{Aesthetics of Rasa: Textual and Performed Understandings}

In the traditionally Hindu dance form of Bharata Natyam, performers tell the stories of the gods

KATHERINE C. ZUBKO is a doctoral candidate at Emory University, U.S.A., in the program of West and South Asian Religions, specializing in Hinduism and Islam. Her interests in performance, aesthetics, and religion and the body stem from her own dance training in Bharata Natyam over the last nine years. Having returned from a year of fieldwork in India as a Fulbright Fellow, she is in the middle of completing her dissertation entitled Embodying Bhakti Rasa: Dancing Across Religious Boundaries in Bharata Natyam. This article was first presented at the American Academy of Religion, Southeast Region, Winston-Salem, North Carolina, March 2005. The fieldwork for this study was conducted in London 2004 with the generous help of the University Fund for Internationalization, Emory University. 
and goddesses through hand and facial expressions in combination with rhythmic and graceful footwork. Born and cultivated in a temple atmosphere, these dances were seen as embodied offerings, akin to the beauty of a flower left lovingly at the feet of the deity. Against the ongoing background and continued practice of Hindu devotion connected to Bharata Natyam, a process of secularization occurred in the 1930's, producing different contexts for the dance, and different roles - including its designation as a classical Indian dance, representative of a national art form. One of the effects of this secularization included the gradual incorporation of thematic and practical content from Christian, Muslim, Buddhist, and other religious traditions. At the same time, the Hindu roots of the dance tradition became more embedded through the framing of the reformulated dance practice through Sanskrit texts on aesthetics. In particular, dancers began to view the 2,000 year-old Natyasastra, ${ }^{107}$ or Treatise on Dance-Drama, as the dance manual par excellence, to be emulated in their own practices as a way of attempting to align the dance form to its ancient, and what some claim to be its most authentic state. ${ }^{108}$ While some dance movements were remolded to match the detailed descriptions found in this and other claimed dance texts, ${ }^{109}$ it was later that the chapter on rasa, or aesthetic mood, was keenly embraced for its theories on generating ideal audience responses.

This chapter in the Natyasastra, as the earliest extant text on rasa, became the foundation for the development of philosophical and literary conversations about the nature of aesthetic enjoyment which hinged upon a metaphor of "tasting" different emotional moods or flavors known as rasas. Theories on rasa mechanically map out what ingredients are necessary for a knowledgeable spectator to savor one's own personal engagement with an art form. In the theoretical formula, vibhava-s, or different situational cues (e.g., moonlight, smell of jasmine, a secluded grove) combine with the physical responses of anubhava-s (e.g., flirtatious side-long glances, demurely looking down, clasping ones hands behind one's back and hunching the shoulders), and fleeting emotional states of vyabhicari-bhava-s (e.g., shyness, jealousy, playfulness) to create sthayibhava-s, or more permanent primary emotions (e.g., rati, or love). When these sthayi-bhava-s are appreciated or tasted by an audience participant, they become known as rasas (e.g., sr ngara, or erotic love). The nine rasas of erotic love, humor, fear, heroism, fury, disgust, wonder, compassion, and sometimes tranquility are the commonly listed aesthetic moods that artists ideally want their audiences to enjoy.

Modern Bharata Natyam dancers and scholars refer to this aesthetic recipe from the Natyasastra when discussing the production of rasa. And yet, bhakti, or a devotional, rasa, which is explicitly absent from the Natyasastra and other Sanskrit aesthetic texts referred to by these contemporary performers, is the most often mentioned rasa discussed in current speeches, writings, program notes, and interviews. Many even cite bhakti rasa as the basis for all Bharata Natyam. ${ }^{110}$ While there is a fully developed theoretical understanding of bhakti rasa centered around Krsna in the $16^{\text {th }}$ c. writings of Rupa Gosvamin found in Gaudiya Vaisnavism, ${ }^{111}$ the dancers never mention these texts or the practitioners of this group when discussing bhakti rasa. According to a performance perspective that pays attention to the contextual framing constructed by the practitioners themselves, this disqualifies Rupa Gosvamin as a primary source for the interpretation of bhakti rasa within the context of Bharata Natyam. In order to give preference to the ways in which dancers frame their own understandings of bhakti rasa, I will follow Charles Briggs' notion of "contextualization clues." According to Briggs, these cues "signal which features of the physical, social, and linguistic setting are being utilized at the time in creating interpretive frameworks for deciphering the meaning of what is being said," 112 or in this case, what is being danced. In this way, the context emerges in each ethnographic instance, created within the process of the performance itself by the participants. This performance-centered approach reveals shifting formulations and understandings of bhakti rasa that would 
otherwise remain unknown if only the aesthetic texts are turned to for authoritative explanations.

Although I would argue that practitioners of Bharata Natyam performatively define bhakti rasa in different ways, ${ }^{113}$ the contextualization cues in the Kalai Kaviri performances of the Gayatri mantra specifically situate bhakti rasa within a primarily cultural framework. Through an enacted bhakti rasa, culturally framed, space is created for the entry of Indian-Christian devotional understandings of Gayatri mantra to intermingle with already existing Hindu understandings. By a cultural reading of bhakti rasa, I mean the conceptual move on the part of the dancers to detach from a particularly Hindu definition of bhakti in favor of an Indian secular framework. Devotion is not Hindu devotion anymore, but in the secular understanding of Indian society, can apply to all the different religions practiced. ${ }^{114}$ This is enhanced by a view of rasa as a de-personalized, distancing of emotion that spectators appreciate as a universalized aesthetic mood operating as a shared cultural aesthetic also not invested in any contextualized religious tradition. With this foundation, the Gayatri mantra, associated with Hindu devotion, addressing Hindu deities, situated in Vedic literature and tied to important Hindu ritual practices, is expanded beyond an exclusive Hindu identity in favor of being a prime representative of Indian culture through the embodied interpretation of the dancers. ${ }^{115}$

\section{Gayatri Mantra}

Om bhur bhuvah svah

Tat savitur varenyam

Bhargo devasya dhimahi

Dhiyo yo nah pracodayat

Gayatri mantra ( $\operatorname{Rg}$ Veda 3.62.10), honored as Vedamata, Mother of the Vedas, ${ }^{116}$ holds a privileged place in Hindu ideology and practice, as it is the first mantra taught to a boy of the twice-born castes at his initiation, or Upanayana-samskara. A general translation reads "Om, earth, atmosphere, sky. Let us meditate on the light of the sun god Savitr. May he guide our intellect." ${ }^{117}$ Although originally considered to be esoteric knowledge, this mantra, adopted by groups such as the Arya Samaj, now encapsulates a widespread core Hindu practice. The chanting of this mantra at dawn and dusk by millions of Hindus is primarily a part of the Sandhya ritual, which also includes bathing, pranayama (breath control), and a salutation and offering of water to the sun. Gurus and books published for the masses encourage the consistent repetition of this mantra by anyone in order to bring both worldly and spiritual benefits, such as prosperity, longevity, purification of negative karma, and self-realization. ${ }^{118}$ The four lines of the mantra have been read in various ways, with Savitr, the Vedic name for the sun god Surya, noted as the main addressee. ${ }^{119}$ Devi as Universal Mother or Savitri (the personification of the mantra as a goddess), and Visnu as Narayana/Hari are also primary recipients for some devotees. ${ }^{120}$

There have been lengthy commentaries written on the meaning of these four lines, ${ }^{121}$ including nuances based on the devotee's primary deity or a more universalistic interpretation regarding a Creator deity who represents the light, rather than a sun god in particular. ${ }^{122}$ While these commentaries provide insight, detailing connections made between Gayatri mantra and other texts, I will now turn to what I will call a performed commentary of Gayatri mantra which utilizes the contextualization cues to add to the meaning of the mantra. For this paper, these cues are drawn from written sources such as program souvenirs and song sheets, and oral sources such as English voice-overs, the choreographers' own description of the movements, and participant comments. In addition, I also will incorporate embodied sources through my observations of the interplay of dance movement and context in eight different performances that ranged from Catholic masses in cathedrals, an Anglican wholeness and healing service, to programs in Hindu temples.

First of all, the background of who and what Kalai Kaviri is, and the placement of Gayatri mantra within its overall dance repertoire, in comparison to typical programs of Bharata Natyam, all must be noted as part of the 
larger embedded contextual information. Kalai Kaviri is a College of Fine Arts specializing in conferring degrees in Indian classical music and dance. Father S.M. George founded the institute in 1977 as a communication center within the Diocese of Tiruchirappalli, guided by a vision of deepening the inculturation of the Church in South India through indigenous dance, music and dramatic mediums focused on incorporating Gospel and social value themes. With the financial support of primarily European missionary organizations, and the blessings of a succession of chief ministers in Tamil Nadu, the communication center developed into a government aided college, affiliated to Bharathidasan University. The college is composed of half Hindu and half Christian students, and both learn a repertoire that includes traditional Hindu themes, as well as Christian ones. The literature of the school focuses on the promotion of Indian classical culture, making it available to all segments of society, which includes backwards and other castes outside of the current majority of uppercaste Brahmins engaged in the practice of Bharata Natyam. The mission of the college also aims to de-centralize the Hindu identity of these cultural arts by including students and choreographed themes from other religions,' particularly Christianity. The dance troupe regularly performs in a variety of settings, from church services to festivals at Hindu temples. ${ }^{123}$

In terms of the dance repertoire specific to Kalai Kaviri during the British tour, the Gayatri mantra was always the first item performed, but was framed differently each time depending on the intended audience and purpose. Other dance items followed it, chosen based on liturgical versus ticketed program settings. These included gospel or parable interpretations, folk dances, socially relevant dance-drama vignettes, and dances drawn from other Indian classical traditions with and without storytelling involved. ${ }^{24}$ However, Gayatri mantra was consistently the first impression to set the tone for all the other dance items, and was often noted by both worship and audience participants for its impact in inviting people into a devotional frame of mind. ${ }^{125}$ The program notes and voice-over confirm this devotional aim, stating that the dancers "dance with a spirit of devotion," or bhakti. The intended predominant mood of bhakti rasa is thus cued through written and oral modes of communication in preparation for its embodied presentation in all of the performance contexts.

In comparison to contemporary Bharata Natyam recitals, the Gayatri mantra served to replace the traditional opening dance items, a namaskaram followed by either an alarippu, or puspanjali. Namaskaram is a short series of movements in which the dancer asks forgiveness from the Earth goddess for bearing the stamping of his/her feet and requests blessings from his/her gods, gurus, and those who are about to watch the dance. The alarippu that follows is an offering of the body through introducing isolated movements in three tempos and in three levels of body positioning (standing, dance-sitting, and full-sitting). The puspanjali sanctifies the dance space and ends in the dancer sprinkling flowers on the stage in homage to the deities, especially Nataraja, Siva as Lord of the Dance. Performances of Gayatri mantra retain an invocatory devotional meaning when they take the place of these traditional bhakti oriented dance items. The Gayatri mantra meets certain expectations of these opening dance items through the depiction of a deity being honored, offered flowers, his feet being touched and brought to the eyes, and the repeated use of the namaste, or prayer position, gesture.

While a thorough analysis of each movement is beyond the scope of this paper, I have chosen to focus on two themes that are highlighted prominently through the actions of the dancers, namely light and lotus imagery. In terms of light, the written program and oral voice-over accompanying this dance item declare Gayatri mantra as worship of a god who is the light, leaving it ambiguous as to exactly which deity it is. However, the hand movements of the dancers incorporate a two-handed gesture used for Jesus created by Father Francis Barboza, a priest and dancer on Christian themes in Bharata Natyam. ${ }^{126}$ During Christian liturgical services, the passage from John 8:12 in which Jesus declares, "I am the Light of the 
World; he who follows me will not walk in darkness, but will have the light of life," was sometimes spoken either prior to the dance, or after by the priest as further confirmation of the intended deity being invoked. This gesture for Jesus is embedded within the motion of a circular arc normatively used to communicate the rising sun or the passage of a day in Bharata Natyam. ${ }^{127}$ While this layering of gestures conveys the overall concept of the rising sun, and thus the sun god Savitr who is addressed in the mantra, it now also indicates Jesus as light. The choreographer herself clarifies the potential dissonance here and its resolution when she states:

It is strange as Christians to perform the Gayatri Mantra, since it is a worshipping of the sun god. But since Christians don't worship the sun god, it can be taken as light, and thus is not only for Hindus. ${ }^{128}$

Through dance, then, both the Hindu and Christian meanings are held simultaneously, and yet also shift depending on the context and the viewer.

Other movements also portray the idea of light. With the arms stretched overhead, fingertips touching, the outline of a flame comes to mind. With this shape kept in tact, a physical embodying of the individual votives that they carried in initially, the dancers perform a series of movements that imitate the flickering of flames in three dominant patterns noted by audience members. The first pattern is in a row, which some said were like the dipam or lamps of Dipavali, the Hindu festival of lights; the second a staggering of individual lights bouncing up and down; and third, in a circle pattern with a predominant flame in the middle. In this latter pattern, a central dancer is partially hidden by the other four dancers arching in over her halfseated figure, and then revealed as she rises tall and shimmering while the surrounding dancers lower into full dance-sit position. In addition to these light patterns, the double message of sun $\operatorname{god} /$ Jesus as light of the world marks both the beginning and end of the dance item through the fanned out bodies of the dancers imitating the rays of the sun. All of these movements are done in the physical presence of a vilukku, or traditional brass Indian lamp, which was lit in the dance space by the dancers themselves just prior to the music beginning. Set against this physical lamp, the embodied layering of flame and sun imagery reinforces and gives expression to the primary theme of the Gayatri mantra, literally a meditation on light.

The other major motif found in the performed Gayatri mantra is the lotus. Although lotuses, and flowers in general are not mentioned at all in the mantra, the choreographer makes distinctive use of the hand gesture for lotus in several different ways. ${ }^{129}$ The first reference to lotus prefaces the portrayal of the sun god/Jesus, indicating the lotuspedestal upon which he sits, a common Indian characteristic for any divine being. ${ }^{130}$ The second use denotes a close relationship between the divine and human, which the choreographer explained to me as "When in God we bloom like the lotus.". This personalizes the mantra, using the blooming lotus as a metaphor for potential self-fulfillment. And last, the opening and closing of the lotus is indicated in the hiding and revealing of the central dancer noted earlier also as a light metaphor, with the arching of the dancers' bodies also forming a closed bud that then opens as the petal-like dancers bend out. The idea of a lotus being like a thousand-petal sun $^{131}$ is evoked vividly in this image, tying the two primary images of light and lotus back together. It should be noted here that Bharata Natyam dancers give a semi-literal translation of lyrics into gesture maybe once through, but then there are repetitions in which meanings are layered on, in commentarial fashion, as is evidenced through these uses of lotus images as a way of building and expanding upon the meaning of the Gayatri mantra. In these performances, the body illustrations of lotuses help mark the presence of the divine, make allusions back to the sun, and are metaphors for successful devotees.

The gestures, movements, and physical images of light and lotus, associated in Indian culture with divinity, contribute to the creation 
of the overall primary rasa, or aesthetic mood of devotion, bhakti rasa. The offering of flowers and light occurs in India as part of Hindu, Christian, and Muslim acts of interaction with the sacred. ${ }^{132}$ Even in this Gayatri mantra, flowers are offered, and the lotus-feet of the divine being are touched and taken into one's heart. The sun god/Jesus is honored through anjali, or prayer gesture, also arguably now a part of an embodied "Indian" vocabulary, which is not the privilege of any one religious tradition in India. These movements that center around light and lotus imagery, combined with Kalai Kaviri's larger mission of promoting classical Indian culture, and the location in the repertoire of the Gayatri mantra as a replacement to traditionally invocatory items, successfully produce a performed culturally framed bhakti rasa that allows for inter-religious meanings to co-exist.

\section{Devotional Bodies and Religious Categories}

The body, as a focus of study, has been approached through almost every disciplinary field, creating a patchwork of theories from anthropology, philosophy, sociology, and gender studies, to name a few. However, as Barbara Holdrege acknowledges, there is a relative lack of body theorizing from within religious studies in comparison to other fields. To correct this methodological omission in her own specialty of Hinduism, Holdrege outlines what the unique perspective of religious studies has to offer. She proposes the construction of a ritual body, ascetic body, and purity body in collaboration, respectively, with the specific Hindu textual traditions of the Vedic Samhita-s and Brahmana-s, Upanisad-s, and Dharmasastra-s. Important for this paper, is that she hints at the construction of a "devotional body," which in her schematic structure would be related to bhakti texts, although she did not elaborate on this pairing. ${ }^{133}$ This study promotes theorizing of a devotional body through not only noting how texts inform and create the bodies of practitioners, as Holdrege models, but also includes what the body experiences and creates through devotional practices.
With the Bharata Natyam dancers of the Gayatri mantra performances, we see a type of devotional body that negotiates religious boundaries in a way that complicates what many founding religion scholars, such as W.C. Smith, traditionally understand the role of devotion to be: a reinforcement of something already believed in. ${ }^{134}$ To interpret these performances, one cannot begin with belief and proceed to interpret everything through solely either Hindu or Christian lenses. In these instances, a performed Gayatri mantra is providing an example of how the knowledge of the body points to a fluidity of devotion in certain contexts based on the marriage of a secularized bhakti and de-personalized, universalized rasa.

To summarize, in the Gayatri mantra performances, bhakti rasa is framed to be read culturally through combining the written, oral, and embodied messages emergent in the performances as contextualization cues. This cultural reading of bhakti rasa defines a "devotional body" . that moves across circumscribed religious traditions, and can sustain, in the case of Gayatri mantra, both Hindu and Christian meanings. Performed aesthetics provides its own clues as to how a performance should be read in certain contexts. In this way, the context emergent within a performance may point towards shifting political, ethical, cultural or devotional meanings, rather than solely Hindu or Christian categories. For a Christian witnessing this Gayatri mantra in a cathedral, devotion towards Jesus may be experienced, while a Hindu in the temple might read a puja to the sun god through the same movements, and yet both these readings co-exist and inform each other, along with other epistemologies about Gayatri mantra, through a shared culturally cued aesthetic foundation. Overall, the embodied knowledge about Gayatri mantra performed here, intermingled with other forms of knowledge, expands upon and challenges not only what we know about Gayatri mantra, but also the present boundaries assumed by the academic definition and categorization of religious practices. 
${ }^{105}$ Savitr is an early Vedic name for Surya, the sun god. See Klaus Klostermaier, A Survey of Hinduism, second edition (New York: State University of New York, 1994), p. 139.

${ }^{106}$ In this essay, I will follow the common Indian English usage for Bharata Natyam as a proper name that does not require italics to denote a non-English word.

${ }^{107}$ Manmohan Ghosh, ed., Natyasastra Ascribed to Bharata-Muni, 2 vols. (Calcutta: Manisha Granthalaya Private Ltd., 1967).

${ }^{108}$ See Padma Subrahmanyam, Natyasastra and National Unity (Kerala: Sri Ramavarma, 1997).

${ }^{109}$ Another important dance related text is Manomohan Ghosh, ed. and trans., Abhinayadarpanam of Nandikesvara, third ed. (Calcutta: Manisha Granthalaya, 1997).

${ }^{110}$ See Anne-Marie Gaston, "Dance and the Hindu Woman: Bharatanatyam Re-ritualized," in Roles and Rituals for Hindu Women, ed. Julia Leslie (Delhi: Motilal Banarsidass, 1992), pp. 149-171; Personal interview with V.P. Dhananjayan, May 10, 2004.

${ }^{11}$ See David L. Haberman, trans., The Bhaktirasamrtasindhur of Rupa Gosvamin (Delhi: Indira Gandhi National Centre for the Arts and Motilal Banarsidass, 2003).

${ }^{112}$ Charles Briggs, Competence in Performance: The Creativity of Tradition in Mexicano Verbal Art (Philadelphia: University of Pennsylvania Press, 1988), p. 15.

${ }^{113} \mathrm{I}$ argue in my dissertation for shifting devotional, cultural, political, and ethical meanings of bhakti rasa based on a performative understanding of aesthetics exemplified in contemporary Bharata Natyam practices.

${ }^{114}$ For example, see A.J. Appasamy, Christianity as Bhakti Marga, (Madras: Christian Literature Society, 1930).

${ }^{115}$ For some, the displacement of the Gayatri mantra from an explicitly Hindu context raises issues of religious appropriation, especially when adopted by another tradition for ritual. Although recognizing this perspective, the focus and scope of this article will remain on the particular Hindu and Christian audience responses during performances given in London and surrounding areas during 2004. Within both Hindu temples and Christian churches, the responses were equally positive.

${ }^{116}$ P.S. Waiker, The Glories of Gayatri (Bangalore, Gurukrupa Prakashan, 1990), p. 1.

${ }^{117}$ Along with my own translation, I've also consulted Gavin Flood, An Introduction to Hinduism (Cambridge: Cambridge University Press, 1996), p.
222; and Bruce Sullivan, The $A$ to $Z$ of Hinduism (Maryland: Scarecrow Press, 2001), pp. 200-1.

${ }^{118}$ Sadguru Sant Keshavadas, Gayatri: The Highest Meditation (London and NY: Kegan Paul, 1993), p. 58.

${ }^{119}$ Klostermaier, Survey, p. 139.

${ }^{120}$ Keshavadas, Gayatri, p. 1.

${ }^{121}$ See P. Ganapatisastri, Gayatribhasyam (Palghat:

Educational Supplies Depot, 1986).

${ }^{122}$ Keshavadas, Gayatri, p. 1. For a Christian Sandhya ritual that includes Gayatri mantra, see D.S. Amalorpavadass, ed., Indian Christian Spirituality (Bangalore: National Biblical Catechetical and Liturgical Centre, 1982), pp. 370-382.

${ }^{123}$ Resurgence: Ambitions and Accomplishments, Kalai Kaviri Silver Jubilee Souvenir (Tiruchirappalli: Kalai Kaviri, 2002). The institutional and foreign missionary support of Kalai Kaviri, Dravidian political interests, and the long time strategy of inculturation/indigenization within the churches of India are all important factors that would be pertinent for a complete contextual analysis of the Kalai Kaviri performances, which, due to space constraints, are beyond the scope of this paper. It would be particularly important to mark these influential contextual differences in comparison to individual performers of Bharata Natyam who choreograph Christian or other non-Hindu themes outside of such frameworks for a variety of religious and nonreligious reasons.

${ }^{124}$ The other Indian classical dance traditions are Kuchipudi, Odissi, Manipuri, Kathak, Kathakali, and Mohini Attam. Kalai Kaviri incorporated Kuchipudi, Kathak, and Mohini Attam on the tour.

${ }^{125}$ Based on audience interviews, June 2004.

${ }^{126}$ Francis Barboza, Christianity in Indian Dance

Forms (Delhi: Sri Satguru Publications, 1990), pp. 198-200. Right hand - Ardhapataka (palm stiff and facing forward like a "stop" gesture, fingers touching together, ring finger and little' finger bent at middle knuckles); Left hand - Alapadma (Open palm, fingers spread and staggered, but held stiff, turning around the little finger), place directly under the right hand in Ardhapataka.

${ }^{127}$ Right hand - Pataka (flat palm, facing forward), held to right of body, Left hand - Mukula (bud, fingers all touching and facing up), held in front of right hand. While holding right hand in place, left hand changes from Mukula, making an arc over the head and resting to the left of body in Tripataka (flat palm, facing forward, ring finger bent at middle knuckle). In the Kalai Kaviri performances, Barboza's gesture for Jesus replaces these hand 
44 Katherine Zubko

gestures, but still moves from the right side of the body, arcs overhead, and then rests to the left side of the body, both hands moving together as a single unit. Illustrations of these hand gestures can be found in a number of books on Bharata Natyam, including Anne-Marie Gaston, Siva in Dance, Myth and Iconography (Delhi: Oxford University Press, 1982), pp. 36-43, as well as classically in Ghosh, Abhinayadarpanam, pp.70-76.

${ }_{128}$ Personal Interview, Stella Marie, June 2, 2004.

${ }^{129}$ Alapadma, see n. 23.

${ }^{130}$ Heinrich Zimmer, Myths and Symbols in Indian Art and Civilization, ed. Joseph Campbell (NJ: Princeton University Press, 1946), pp. 90-102.

${ }^{131}$ Zimmer, Myths, 90.

${ }^{132}$ Vasudha Narayanan, "The Strains of HinduMuslim Relations: Babri Masjid, Music, and Other Areas Where the Traditions Cleave," Hinduism and Secularism: After Ayodhya, ed. Arvind Sharma (New York: Palgrave, 2001), pp.159-202.

${ }_{13 \hat{3}}$ Barbara Holdrege, "Body Connections: Hindu Discourses of the Body and the Study of Religion," International Journal of Hindu Studies 2, 3 (December 1998):341-386:

${ }^{134}$ See W.C. Smith, The Meaning and End of Religion: A New Approach to the Religious Traditions of Mankind (New York: New American Library, 1962). 